ROCZNIKI NAUK SPOŁECZNYCH

Tom 11(47), numer 1 - 2019

DOI: http://dx.doi.org/10.18290/rns.2019.47.1-4

ARTUR DRZEWICKI

\title{
PROBLEM NATO \\ W RELACJACH NIEMIECKO-UKRAIŃSKICH W XXI WIEKU. ZARYS ZAGADNIENIA
}

Objęcie władzy przez koalicję SPD/Bündnis 90/Die Grünen (1998-2005) ugruntowało istniejące w polityce zjednoczonych Niemiec przekonanie, iż rozwijanie długotrwałych, partnerskich i opartych na zaufaniu pogłębionych relacji z Rosją stanowi jeden z głównych warunków osiągnięcia europejskiego bezpieczeństwa, a także przezwyciężenia regionalnych i globalnych zagrożeń. Fakt ten w sposób istotny wpłynął na dość wstrzemięźliwe podejście do zarysowanej przez Kijów koncepcji zbliżenia z Sojuszem Północnoatlantyckim (NATO) z członkostwem w jego strukturach włącznie - która pojawiła się w 2002 r. Było to tym bardziej istotne, iż problematyka ta $w$ relacjach niemiecko-ukraińskich zaczęła po raz pierwszy być definiowana przez pryzmat rozważań nad możliwością i realnością procesu integrowania Ukrainy z paktem, nie zaś - jak było to w okresie rządów koalicji chadecko-liberalnej (1990-1998) - zagrożeń wynikających dla państwa ukraińskiego z tytułu jego rozszerzenia o kraje Europy Środkowej. W latach 1995-1998 relacje Kijowa i Bonn były bowiem zdominowane przez tę właśnie kwestię. Tym samym główne rozważania koncentrowały się wówczas wokół problemu zdiagnozowania zagrożeń dla państwa ukraińskiego, wynikających z procesu rozszerzenia oraz znalezienia rozwiązania, które nie tylko rozwiałoby obawy władz w Kijowie, ale również ukształtowałoby płaszczyznę współpracy Ukrainy z NATO. Namacalnym dowodem tego rodzaju podejścia był osiągnięty wśród niemieckich elit politycznych konsensus co do zasadności sformalizowania relacji Ukrainy i Sojuszu Północnoatlantyckiego w postaci odrębnego porozumienia (Karta o szczególnym partnerstwie NATO-

Dr ARTuR DRzewicki - Instytut Studiów Międzynarodowych, Uniwersytet Wrocławski; adres do korespondencji: ul. Koszarowa 3, 51-149 Wrocław; e-mail: artur.drzewicki@uwr.edu.pl; ORCID iD: https://orcid.org/0000-0003-4271-6632 
-Ukraina, podpisana w 1997 r.), jako realnego sposobu na podniesienie znaczenia tego państwa w Europie i jego ochronę przed negatywnymi skutkami pozostawania w „szarej strefie bezpieczeństwa” ${ }^{1}$.

Wspomniane wyżej uznanie wyjątkowej roli państwa rosyjskiego w niemieckiej polityce można uznać za fakt obiektywny, który wynikał i nadal wynika choćby $\mathrm{z}$ międzynarodowej pozycji tego kraju, jego potencjału militarnego i surowcowego czy też położenia geograficznego. Tym samym konieczność uwzględnienia przez Berlin przesłanek determinowanych znaczeniem Moskwy dla europejskiego i światowego bezpieczeństwa jest stałym czynnikiem warunkującym pozycję Niemiec w kwestii rozszerzenia NATO o Ukrainę, którego nieuwzględnienie może prowadzić do niewłaściwego zdiagnozowania dynamiki relacji niemiecko-ukraińskich.

Odnosząc się do ówczesnej polityki Berlina, jak również w decydującej mierze kolejnych rządów niemieckich, można wskazać na kilka podstawowych przyczyn, które tego rodzaju podejście warunkowały i warunkują: po pierwsze, w przekonaniu Republiki Federalnej Niemiec (RFN) Rosja jest państwem, którego stabilność i zrównoważony rozwój wpływają bezpośrednio na całość architektury euroatlantyckiego bezpieczeństwa; po drugie, uznaje się, iż partycypacja Moskwy, jako partnera, w procesach rozwiązywania kryzysów i konfliktów na obszarach tzw. europejskich peryferii oraz kontynentu azjatyckiego, kumulujących największe zagrożenia dla światowego bezpieczeństwa, jest nieodzowna. Po trzecie, działania podejmowane przez Federację Rosyjską (FR) warunkują stabilność obszaru postradzieckiego, w konsekwencji tego jej postawa w dużej mierze określa możliwość rozwijania przez Unię Europejską (UE) i RFN stosunków z poszczególnymi jego krajami - zarówno na płaszczyźnie politycznej, jak i gospodarczej; po czwarte, posiadane zasoby surowcowe oraz potencjalna wielkość rynku zbytu powoduje, iż Rosja, jako partner gospodarczy UE oraz samych Niemiec, może w pewnym zakresie wpływać na rozwój tych podmiotów i ich bezpieczeństwo ${ }^{2}$; po piąte, w nowych uwarunkowaniach niemieckiej polityki bezpieczeństwa Rosja stanowi istotny czynnik warunkujący realizację koncepcji

1 Zob. szerzej: A. DRZEwICKI, Europa Środkowa $i$ Wschodnia $w$ polityce bezpieczeństwa Republiki Federalnej Niemiec 1990-1998. Stanowisko niemieckich partii politycznych, Torun: Wyd. Adam Marszałek 2010, s. 207-217.

${ }^{2}$ A. SCHWAll-Düren, Polacy i Niemcy - partnerzy w ksztaltowaniu aktywnej polityki wschodniej? Wyktad ku czci Willy Brandta, XII 2006 r., Warszawa: Fundacja im. Friedricha Eberta 2006, s. $19-20$. 
„wysuniętej ochrony” terytorium państwa niemieckiego przed zagrożeniami $\mathrm{z}$ zewnątrz ${ }^{3}$.

Istotnym determinantem polityki rządu „czerwono-zielonego" było rozpoczęcie „wojny z terroryzmem” (2001), w wyniku której doszło do „geograficznego i instytucjonalnego rozszerzenia celów", stojących przed niemiecką polityką w sferze bezpieczeństwa. Skutkowało to nie tylko zwiększonym zaangażowaniem władz niemieckich na rzecz światowej stabilności, przede wszystkim opartym na aktywnej dyplomacji prewencyjnej, pomocy rozwojowej oraz udziale Bundeswehry w operacjach pokojowych (reagowania kryzysowego), realizowanych poza obszarem europejskim, ale również wzmożonym wykorzystywaniem dla osiągnięcia wyznaczonych celów mechanizmów pozostających w dyspozycji struktur multilateralnych, takich jak NATO, UE, ONZ i OBWE ${ }^{4}$. Zachodzące w tym czasie przeobrażenia na kontynencie europejskim oraz nowa wykładnia zagrożeń dla ładu międzynarodowego, w dużej mierze będąca konsekwencją zamachów z 11 września 2001 r., stały się bowiem impulsem do czynnego zaangażowania się Niemiec w procesy pokojowe i stabilizacyjne w regionach znajdujących się także poza obszarem europejskim ${ }^{5}$ oraz do walki z takimi zjawiskami, jak terroryzm międzynarodowy, proliferacja broni masowego rażenia, „kryzysy i konflikty na peryferiach" kontynentu europejskiego (Bliski Wschód, Azja Środkowa, Kaukaz) oraz „państwa upadłe i upadające”. Tego rodzaju geograficzne i instrumentalne rozszerzenie zadań stojących przed niemiecką polityką bezpieczeństwa oraz potwierdzenie znaczenia FR dla realizacji politycznych i ekonomicznych interesów Berlina spowodowało, iż Moskwa stała się naturalnym partnerem w działaniach obliczonych na podejmowanie nowych wyzwań i przezwyciężanie zagrożeń mających znaczenie nie tylko dla europejskiego bezpieczeństwa, ale również globalnego ${ }^{7}$. W ten sposób dotychczasowe postrzeganie stosunków niemiecko-rosyjskich przez pryzmat rozwijania szerokiej współpracy z Rosją w sferze bezpieczeństwa i integrowania jej w procesie kształtowania stabilności obszaru europejskiego zostało znacznie rozszerzone. Kraj ten przez

\footnotetext{
${ }^{3}$ F.J. Jung, Streitkräfte als Instrument einer umfassenden, vernetzen Sicherheits- und Verteidigungspolitik, w: Sicherheitspolitik in neuen Dimensionen, Hamburg-Berlin-Bonn: Bundesakademie für Sicherheitspolitik 2009, s. 42.

${ }^{4}$ S. Sedlmayr, Die aktive Aussen- und Sicherheitspolitik der rot-grünen Bundesregierung 1998-2005, Wiesbaden 2008, s. 133-140.

${ }^{5}$ F. KNÜPLING, Od Bałkanów do Hindukuszu. Czerwono-zielona polityka zagraniczna przed nowymi wyzwaniami, „Dialog. Magazyn Polsko-Niemiecki” 2005, nr 69-70, s. 25.

${ }^{6}$ Verteidigungspolitische Richtlinien. Nationale Interessen wahren - Internationale Verantwortung übernehmen - Sicherheit gemeinsam gestalten, Bundesministerium der Vertedigung, Berlin den 27. Mai 2011, http://www.bmvg.de, s. 1-2.

${ }^{7}$ Stosunki Rosja-Niemcy w latach 1998-2005, Raport OSW/CSM, Warszawa, II 2006, s. 6.
} 
zdecydowany okres czasu (przynajmniej do 2014 r.) postrzegany był przez władze niemieckie przede wszystkim jako państwo partnerskie, które z racji swojego potencjału posiada mechanizmy aktywnego oddziaływania na nowe formy zagrożeń i ich przezwyciężania nie tylko na terenie Europy (np. ,zamrożone konflikty"), lecz także poza nią. W konsekwencji włączenie go w system euroatlantyckiego bezpieczeństwa i przekazanie mu odpowiednich wartości i norm miało dla Berlina znaczenie priorytetowe. Tego rodzaju krok pozwalał bowiem zawrócić Moskwę z jej „specjalnej, euroazjatyckiej drogi” i wykorzystać jej potencjał dla dobra europejskiego bezpieczeństwa ${ }^{8}$. Dobitnie ujął to w późniejszym czasie minister spraw zagranicznych z ramienia SPD w rządzie „wielkiej koalicji” Frank-Walter Steinmeier, stwierdzając, iż bez konstruktywnego zaangażowania Moskwy nie da się rozwiązać „bodaj żadnego z aktualnych konfliktów - od Iranu po Bliski Wschód, od Korei Północnej po Kosowo"".

Zdefiniowana w ten sposób zasada Russia First, która w sposób jednoznaczny wyklarowała się właśnie na przełomie XX i XXI wieku, określała Ukrainę jako istotny, ale nie priorytetowy podmiot systemu europejskiego bezpieczeństwa. Sama zaś koncepcja rozszerzenia NATO o Ukrainę, będąca esencją zarysowanej przez Leonida Kuczmę idei euroatlantyckiego kursu Kijowa ${ }^{10}$ - w dużej mierze będącego konsekwencją odejścia od polityki „dryfu politycznego" i pewnego zdystansowania się względem Moskwy - co prawda została zauważona przez Berlin, niemniej jednak traktowano ją jako propozycję politycznie nie do końca przemyślaną, za którą, poza samą deklaracją, nie szła żadna realna wartość. Co więcej, stała ona niejako w sprzeczności z wizją rządu Gerharda Schrödera, która zakładała konieczność „multilateralnego” kreowania nowego systemu europejskiego i światowego bezpieczeństwa, z założenia bazującego na prymacie prawa międzynarodowego i współpracy silnych instytucji międzynarodowych $^{11}$. Za postrzeganiem kroku Kijowa jako czynnika antagonizującego Rosję szło bowiem dodatkowo przekonanie, iż kwestia ta może stać się również elementem budowania i wzmacniania w europejskiej przestrzeni amerykańskiej, neokonserwatywnej, narodowej wizji bezpieczeństwa (prezydentura Georga W.

\footnotetext{
${ }^{8}$ Por. M. BuhBe, Grundzüge einer deutsche Russland-Strategie, w: Deutschland in den internationalen Beziehungen. Ziele, Instrumente, Perspektiven, III, Bonn-Berlin: Freidrich Ebert Stiftung 2007, s. 8.

${ }^{9}$ F.W. STEINMEIER, Dialog obywateli. Berlińskie przemówienie ministra spraw zagranicznych Niemiec $z$ okazji 20-lecia powstania Federalnego Zwiazku Towarzystw Niemiecko-Polskich, 30 IV 2007, „Dialog. Magazyn Polsko-Niemiecki” 2007, nr 77-78, s. 87.

${ }^{10}$ Zob. szerzej: M. PIETRAś, Stosunki Ukrainy z Sojuszem Pótnocnoatlantyckim, w: Ukraina w stosunkach międzynarodowych, red. M. Pietraś, T. Kapuśniak, Lublin: Wydawnictwo UMCS 2007, s. 360-365.

${ }^{11}$ Stosunki Rosja-Niemcy w latach 1998-2005, s. 7.
} 
Busha, 2001-2009). Dowodem dla zasadności tego rodzaju twierdzenia miało być między innymi poparcie udzielone przez Ukrainę Waszyngtonowi przed i w czasie tzw. II wojny w Zatoce Perskiej (2003), a następnie zaangażowanie ukraińskiego kontyngentu wojskowego w operację stabilizacyjną w Iraku (20032005). W przekonaniu RFN zaprezentowana przez rząd w Kijowie idea integracji państwa ukraińskiego z NATO było swoistym tematem zastępczym, odciągającym uwagę od rzeczywistych problemów tego kraju, przejawiających się w permanentnych politycznych, jak i społeczno-ekonomicznych kryzysach. Dlatego też nawoływano władze w Kijowie do skupienia się przede wszystkim na prodemokratycznych reformach państwa, których realizacja pozwoliłaby dać mu w przyszłości „europejską perspektywę”, rozumianą przede wszystkim jako postępującą integrację tego kraju z UE, choć niekoniecznie zakończoną członkostwem $^{12}$. Tym samym należy uznać, iż przedstawiona przez rząd niemiecki koncepcja eurointegracyjna, za którą poszły dość realne działania Berlina na rzecz zbudowania spójnej wizji europejskiej przyszłości Ukrainy, nie stanowiła alternatywy dla euroatlantyckich dążeń Kijowa, lecz była w jego przekonaniu jedyną, realnie możliwą drogą zbliżania tego kraju do Zachodu oraz obowiązującego w nim systemu praw i wartości ${ }^{13}$. W konsekwencji wszelkie działania integracyjne na płaszczyźnie euroatlantyckiej, wychodzące poza naturalne ramy współpracy, określone zapisami Karty NATO-Ukraina, traktowane były z rezerwą, jako nie do końca trwałe i nie odpowiadające realiom europejskiego bezpieczeństwa. Afery związane z taśmami Melnyczenki i systemem radarowym „Kolczuga”, które wstrząsnęły w latach 2000-2002 ukraińską sceną polityczną i podważyły międzynarodową wiarygodność Ukrainy, przekreślając tym samym ukraińskie nadzieje na uzyskanie podczas szczytu NATO w Istambule (28-29 czerwca 2004) Planu Działania na rzecz Członkostwa (Memebership Action Plan, MAP), zostały uznane za najlepszy dowód na słuszność przyjętego przez Niemcy stanowiska. Sytuacja ta zbiegła się zresztą z kolejnym prorosyjskim zwrotem w polityce zagranicznej i bezpieczeństwa Ukrainy, którego kwintesencją było oficjalne ogłoszenie na szczycie rosyjsko-ukraińskim w Jałcie (26 V 2004) zmian w doktrynie obronnej tego państwa, zgodnie z którymi rezygnowało ono z dążeń do uzyskania członkostwa w NATO i UE.

Mimo ogólnie dość przychylnego wobec Ukrainy stanowiska kanclerza G. Schrödera, powołanie w listopadzie 2005 r. w RFN ,wielkiej koalicji” zostało

\footnotetext{
12 Por. S.V. KontratuUK, Evropejska polityka objednanoji Nimeththyny, Kyjiv 2008, s. 191-202.

${ }^{13}$ Wywiad z dr Andrijem Wesołowskim, wiceministrem spraw zagranicznych Ukrainy w latach 2005-2008, przeprowadzony w Kijowie w dniu 25 X 2011 r.; zapis w posiadaniu autora.
} 
odebrane w Kijowie z wielkimi nadziejami ${ }^{14}$. Nowe władze ukraińskie, wyłonione w następstwie ,pomarańczowej rewolucji” (2004), liczyły przede wszystkim na wykrystalizowanie jednoznacznej i przychylnej euroatlantyckim oraz europejskim aspiracjom Ukrainy koncepcji politycznej. Miano nadzieję na ograniczenie panującej dotąd w polityce niemieckiej tendencji postrzegania wydarzeń na obszarze byłego Związku Socjalistycznych Republik Radzieckich (ZSRR) przez pryzmat interesów Rosji i ewentualnych zagrożeń dla niemiecko-rosyjskiego „partnerstwa strategicznego" ${ }^{15}$. Sytuacja ta niewątpliwie pozwoliłaby na sukcesywne pogłębianie przez Kijów integracji z Sojuszem Północnoatlantyckim, już jednoznacznie deklarowanej jako cel państwowy, i potwierdzenie prawa Ukrainy do uzyskania członkostwa w UE. Co prawda wcześniejsze wypowiedzi polityków chadeckich nie wskazywały jednoznacznie, iż tego rodzaju nadzieje władz ukraińskich są zasadne, niemniej jednak wierzono, iż także w tym wypadku dojdzie do długo oczekiwanego przełomu ${ }^{16}$. Wydawać się to może tym bardziej dziwne, iż $\mathrm{w}$ większości wypadków politycy niemieccy mówili wyłącznie o zbliżeniu Ukrainy do struktur UE, w „uprzywilejowanym partnerstwie”, oraz daniu jej „europejskiej perspektywy” czy też udzieleniu pomocy w znalezieniu „Swojego miejsca w Europie”, nie zaś o samym członkostwie ${ }^{17}$. Integracja miała doprowadzić do pogłębienia procesów demokratycznych na Ukrainie oraz ułatwić jej przyjęcie ogólnoeuropejskich wartości, wynikających z określonych tradycji kulturowych. W żadnym wypadku nie miała być ona jednak drogą do osiągnięcia szybkiego członkostwa w Unii. Mając to na względzie, nie może dziwić fakt, iż kwestia przystąpienia Ukrainy do NATO była nadal pomijana w otwartej dyskusji lub podchodzono do niej dość wstrzemięźliwie.

Wkrótce okazało się jednak, iż paradoksalnie stosunki niemiecko-ukraińskie w okresie rządów „,wielkiej koalicji” straciły na swojej dynamice, a stanowisko władz federalnych wobec integracyjnych dążeń Kijowa zasadniczo nie odbiega

\footnotetext{
${ }^{14}$ Koalicja największych ugrupowań niemieckiego parlamentu, a mianowicie CDU i SPD oraz CSU, odtąd nazywana ,wielką koalicją”, została utworzona w dniu 18 XI 2005 r.

15 Zgodnie z założeniami umowy koalicyjnej podpisanej między CDU, CSU i SPD „Partnerstwo Strategiczne" z Rosją miało być nadal rozwijane. Proces ten miał zachodzić paralelnie na dwóch płaszczyznach: bilateralnej i unijnej; Gemeinsam für Deutschland. Mit Mut und Menschlichkeit. Koalitionsvertrag zwischen der CDU, CSU und SPD, Berlin 2005, s. 156.

${ }^{16}$ A. GetmanthuK, Est li u Vas plan, frau Merkel?, „Zerkalo nedeli“, 29 X 2005.

17 Zob. W. SCHÄUBLE, Die europäische Integration voranbringen, „Frankfurter Allgemeine Zeitung”, 28 I 2005; Union für Signal der EU an die Ukraine, „Süddeutsche Zeitung”, 29 XII 2005; Antrag der Abgeordneten Claudia Nolte, Dr. Friedbert Pflüger, Peter Hintze, weiterer Abgeordneter und der Fraktion der CDU/ CSU: Für eine klare europäische Perspektive der Ukraine, Plenarprotokoll 15/178, Deutscher Bundestag, 2 VI 2005; por. CDU/CSU, Deutschlands Chancen nutzen. Wachstum, Arbeit, Sicherheit. Regierungsprogramm 2005-2009, Berlin 11 VII 2005, www.cdu.de/ doc/pdfc/05_07_11_Regierungsprogramm.pdf [dostęp: 10.02.2011].
} 
od podejścia prezentowanego przez wcześniejszą koalicję. Co więcej, w pewnej mierze można uznać, iż polityka rządu CDU/CSU/SPD stała się mniej otwarta na koncepcje włączenia Ukrainy do różnego rodzaju form współpracy ${ }^{18}$, a same stosunki niemiecko-ukraińskie uległy dość widocznemu ochłodzeniu, czego efektem było nieformalne zawieszenie istniejących od 1998 r. międzyrządowych konsultacji ${ }^{19}$.

Tego rodzaju sytuacja miała swoje złożone uwarunkowania. Samo zwycięstwo ,pomarańczowej rewolucji” i pozytywne odebranie tych wydarzeń w RFN wywołało we władzach ukraińskich przekonanie o stałości i niepodważalności zmian, które dokonały się w niemieckiej polityce wobec Ukrainy. Miało to skutkować poparciem dla integracji tego państwa z UE i NATO. Konsekwencją tego było złudne przeświadczenie Kijowa, iż tego rodzaju pozytywny stan rzeczy nie wymaga już większego zaangażowania i podejmowania istotnych zabiegów dla jego podtrzymania. W ten sposób polityka Ukrainy koncentrowała się w relacjach bilateralnych na uzyskiwaniu przychylności czy też aktywnego wsparcia innych państwach, które w jej przekonaniu miały w danym wypadku decydujące znaczenie dla powodzenia integracji z NATO i UE, a mianowicie Stanów Zjednoczonych oraz Francji. Ochłodzenie w relacjach niemiecko-ukraińskich wynikało również $\mathrm{w}$ dużej mierze $\mathrm{z}$ dość niejednoznacznej polityki Kijowa wobec samej RFN oraz wyraźnego braku postępu w zakresie reformowania kraju. Po „pomarańczowej rewolucji” Ukraina dość szybko bowiem znalazła się w permanentnym kryzysie politycznym, który był nie tylko wynikiem rywalizacji obozu władzy z opozycyjną Partią Regionów Ukrainy (PRU), ale również licznych rozdźwięków - z reguły o charakterze ambicjonalnym - do których dochodziło w łonie koalicji rządowej. Nieprzygotowana, politycznie uwarunkowana i wprowadzona jeszcze przez prezydenta Leonida Kuczmę ustawa z dnia 8 XII 2004 r. (tzw. Polireforma), która w sposób nieprecyzyjny regulowała podział uprawnień między prezydentem i premierem, niejako stworzyła dwa równorzędne ośrodki władzy, co utrudniało kształtowanie jednolitej strategii działania w zakresie polityki zagranicznej i bezpieczeństwa. W konsekwencji tego rodzaju stan rzeczy dość szybko wywołał „rozczarowanie” elit politycznych i społeczeństwa niemieckiego. Zbiegło się to z dojściem do władzy kanclerz Angeli Merkel, która co prawda do przemian na Ukrainie podeszła bardziej pragmatycznie i mniej emocjonalnie niż jej poprzednik, za to w większym stopniu starała się ograniczać panującą dotychczas w polityce niemieckiej zasadę Russia First oraz znaleźć

\footnotetext{
${ }^{18}$ Wywiad z dr Andrijem Wesołowskim, wiceministrem spraw zagranicznych Ukrainy w latach 2005-2008.

19 Por. A.I. KUDRJATHENKO, Ukrajinsko-nimecki vidnosyny $v$ konteksti globalnyh zrushen na kontynenti, w: Ukrajina v Evropi: poshuky spilnoho majbutnoho, Kyjiv 2009, s. 204.
} 
trwałe rozwiązanie dla prawno-instytucjonalnego powiązania Kijowa z UE, co jednak nie miało być równoznaczne z członkostwem w tej strukturze.

Całościowo tego rodzaju sytuacja w naturalny sposób wpłynęła również na ocenę i akceptację możliwości pogłębionej integracji państwa ukraińskiego z NATO, które w 2007 r. w swojej Strategii Bezpieczeństwa Narodowego już w sposób formalny uznało członkostwo w Sojuszu za priorytetowy cel polityki zagranicznej i bezpieczeństwa ${ }^{20}$. Jak już wspomniano, zmiana władzy w RFN co prawda w pewnej mierze ograniczyła prorosyjskie tendencje, odzwierciedlane dotąd przez politykę rządu kanclerza Schrödera, niemniej jednak nie spowodowała ona jednoznacznego odejścia od postrzegania problemów Europy Wschodniej przez pryzmat stanowiska Rosji, jako głównego partnera na tym obszarze, zarówno w relacjach bilateralnych, jak i w sferze zintegrowanej polityki europejskiej. W decydującej mierze takie podejście wpływało na utrzymanie sprzeciwu Berlina wobec rozszerzenia NATO o państwa byłego ZSRR, czyli Gruzję i Ukrainę. Ideę „otwartych drzwi” władze niemieckie traktowały (i traktują do dzisiaj) przede wszystkim jako ogólną zasadę funkcjonowania sojuszu, nie zaś jako obligatoryjny wyznacznik celów własnej polityki bezpieczeństwa wobec poszczególnych państw.

Tego rodzaju uwarunkowania, podobnie jak całościowy, ówczesny stan stosunków niemiecko-rosyjskich, znalazły swoje odbicie w postawie kanclerz Merkel podczas szczytu NATO w Bukareszcie (2-4 IV 2008). W jego trakcie delegacja niemiecka jednoznaczne przeciwstawiła się możliwości nadania Gruzji i Ukrainie MAP, uznając, iż kierunek rozwoju sytuacji politycznej i społeczno-ekonomicznej na Ukrainie nie jest zbieżny z procesem euroatlantyckiej integracji. W konsekwencji jedno z najważniejszych kryteriów członkostwa, jakim jest stabilność kandydata, nie jest możliwe do osiągnięcia przez ten kraj w najbliższym czasie. W konsekwencji przyznanie MAP obu państwom uznano za działania przedwczesne ${ }^{21}$. Stanowisko Niemiec uzyskało wsparcie Francji, która uzależniała swoją ostateczną decyzję w tej sprawie od stanowiska kanclerz Merkel, nie zaś od realnej oceny zasadności tego kroku. Oznacza to, iż prezydent Nicolas Sarkozy ostatecznie był gotów poprzeć pomysł przyznania Ukrainie MAP, o ile tego rodzaju koncepcja uzyskałaby przychylność rządu niemieckiego ${ }^{22}$. Osta-

${ }^{20}$ Zob. Ukaz. Prezydenta Ukrajiny nr 105/2007 pro Strategiju nacjonalnoj bezpeki Ukrajiny, 12 II 2007, maszynopis powielany.

${ }^{21}$ V.A. MANZHOŁA, Ukrajina $v$ systemi dvostronnih vidnosyn is providnymi evropejskymi krajinamy, w: Zovnishnja polityka Ukrajiny - 2008: Strategithni ocinky, prognozy ta priorytety, red. G.M. Perepelyci, Kyjiv 2009, s. 273-274.

22 Wywiad z Wołodymyrem Ohryzko, ministrem spraw zagranicznych Ukrainy w latach 20072009, przeprowadzony w Kijowie w dniu 5 VI 2013 r.; zapis w posiadaniu autora. 
tecznie w deklaracji przyjętej podczas szczytu znalazło się ogólne stwierdzenie, iż Ukraina i Gruzja staną się członkami NATO, nie podano jednak konkretnego terminu.

Stanowisko Niemiec zaprezentowane w Bukareszcie spotkało się z krytyką strony ukraińskiej, co niejako zmusiło kanclerz Merkel do zarysowania podczas swojej wizyty w Kijowie (21 VII 2008) idei powołania swego rodzaju zamiennika dla MAP w postaci nigdy do końca niesprecyzowanego „planu pomocy w dążeniu Ukrainy do NATO” czy też „nawigacyjnego planu powiązanego z technicznymi i wojskowymi kwestiami”.

Wojna w Gruzji (2008), jak również rosyjsko-ukraiński kryzys gazowy (2009) powszechnie zostały odebrane jako wydarzenia, które stanowić miały podstawę do weryfikacji przez Niemcy swojej dotychczasowej polityki wobec Moskwy zarówno w wymiarze politycznym, jak i gospodarczym. W powszechnej opinii świadczyło o tym krytyczne stanowisko Berlina wobec działań armii rosyjskiej na Kaukazie, które zaowocowało w dużej mierze bardziej emocjonalną niż przemyślaną zapowiedzią kanclerz Merkel, iż w przyszłości Gruzja i Ukraina będą członkami NATO $^{23}$. Mimo że tego typu stwierdzenie odzwierciedlało w dużej mierze postanowienia szczytu w Bukareszcie, to wkrótce władze niemieckie starały się wyraźnie pomniejszyć znaczenie tej deklaracji, wskazując raczej na jej dogmatyczny aspekt, odnoszący się do potwierdzenia jednej z głównych zasad funkcjonowania Sojuszu Północnoatlantyckiego, jakim jest jego otwartość na nowych członków. Jednocześnie jednak negatywna ocena samodzielnego uznania przez władze rosyjskie niepodległości Abchazji i Osetii Południowej, wyrażona przez rząd w Berlinie, w dużej mierze potwierdzała wcześniejsze przekonanie o ochłodzeniu relacji niemiecko-rosyjskich. Stan ten potwierdzały również doniesienia o gotowości poparcia przez RFN koncepcji przyznania Kijowowi i Tbilisi MAP podczas szczytu Sojuszu w Brukseli (2 XII 2008), do czego jednak ostatecznie nie doszło z powodu pogłębiającego się na Ukrainie kryzysu politycznego (rozwiązanie przez prezydenta Wiktora Juszczenkę parlamentu i kryzys konstytucyjny ${ }^{24}$. Tego typu wydarzenia i interpretacje spowodowały, iż jakby na marginesie ogólnie panujących wśród opinii publicznej oczekiwań, doszło 2 X 2008 r. do wizyty szefa rządu federalnego w Petersburgu. W jej trakcie kanclerz Merkel przyjęła wobec Moskwy wyraźnie ugodowe stanowisko, stwierdzając jednoznacznie, iż ani Gruzja, ani Ukraina nie są goto-

${ }^{23}$ Zob. S. ŻERKO, Niemcy wobec konfliktu w Gruzji (sierpień 2008 r.), „Biuletyn Instytutu Zachodniego” 2008, nr 1; Angela Merkel wpada w furię, „Gazeta Wyborcza”, 5 IX 2008.

${ }^{24}$ V.A. MANZHOLA, Ukrajina v systemi dvostronnih vidnosyn is providnymi evropejskymi krajinamy, s. 274. 
we, aby objąć je planem członkostwa w $\mathrm{NATO}^{25}$. W konsekwencji podczas wspomnianego szczytu w Brukseli kwestia MAP nie została poruszona w sposób oficjalny, zamiast tego obu państwom zaproponowano „ramowy narodowy program reform obronności”, co niejako odzwierciedlało główną tendencję, widoczną wówczas w działaniach Sojuszu: „nie zniechęcać” (Gruzji i Ukrainy) i ,nie drażnić" (Rosji).

Niezależnie od tego, dość wstrzemięźliwa i - jak się wydaje - raczej zachowawcza postawa rządu federalnego wobec rosyjsko-ukraińskiego kryzysu gazowego traktowana była jako forma zawoalowanej krytyki Rosji, znamionująca odejście władz niemieckich od dotychczasowej polityki, obliczonej na utrzymywanie strategicznego wymiaru relacji niemiecko-rosyjskich. Widocznym symptomem przewartościowania dotychczasowych priorytetów było fiasko wizyty ówczesnego premiera Władimira Putina w Berlinie w dniu 16 I 2009 r. Kanclerz Merkel nie tylko nie wyraziła wówczas poparcia dla działań Moskwy w trakcie konfliktu gazowego z Ukrainą, lecz także jednocześnie wyraźnie podkreśliła, iż za jego eskalację w równej mierze odpowiadają obie strony ${ }^{26}$. Wydarzenia te miały stanowić kulminacyjny moment $\mathrm{w}$ procesie postępującego oziębienia stosunków dwustronnych, którego początków upatrywano w 2005 r., z chwilą zwycięstwa CDU/CSU w wyborach do Bundestagu i przejęcia władzy przez kanclerz Merkel ${ }^{27}$. Wyraźne osłabienie personalnych relacji między przywódcami obu krajów w widoczny sposób stało w sprzeczności z dotychczasowymi założeniami polityki niemieckiej wobec Rosji, uosabianej bezpośrednimi kontaktami Schröder-Putin i rozwojem tzw. Dialogu Petersburskiego, który miał stać się oficjalną płaszczyzną kontaktów elit, a w szerszym rozumieniu także społeczeństw RFN i $\mathrm{FR}^{28}$. Jednocześnie próby utrzymania strategicznego wymiaru wzajemnych relacji, a przede wszystkim uznanie współpracy z Moskwą za główny cel nowej polityki wschodniej ${ }^{29}$, propagowanej przez ministra spraw zagranicznych z ramienia SPD - F. W. Steinmeiera podczas prezydencji niemieckiej w UE w pierwszej połowie 2007 r., wywołały ostrą reakcję urzędu kanclerskiego oraz CDU/CSU. Koncepcja ta bowiem w sposób widoczny zgodnie z ideą „zbliżenia poprzez powiązanie” - kierowała główną uwagę na rozwój stosunków UE-Rosja, definiując jednocześnie relacje z pozostałymi kra-

\footnotetext{
${ }^{25}$ Merkel poprawia stosunki z Rosja, „Gazeta Wyborcza”, 3 X 2008.

${ }^{26}$ S. MeISTER, Niemiecki szpagat, „Nowa Europa Wschodnia” 2009, nr 2, s. 50.

${ }^{27}$ Por. J. Trener, Berlin - Moskwa: nowy rzeczowy styl Niemców?, „Dialog. Magazyn PolskoNiemiecki” 2007, nr 77-78, s. 62-66.

${ }^{28}$ S. MeISTER, Niemiecki szpagat, s. 51.

${ }^{29}$ Zob. szerzej: A. DRZEWICKI, Europejska Polityka Wschodnia - doświadczenia i wnioski dla Polski, „Przegląd Zachodni” 2011, nr 3, s. 45-65.
} 
jami postradzieckimi jako ich pochodną, co ostatecznie spowodowało jej odrzucenie $^{30}$. Dodatkowo Berlin, inaczej niż w okresie trwania koalicji SPD/Bündnis 90/Die Grünen, starał się intensyfikować działania obliczone na rozwijanie w ramach UE współpracy z krajami obszaru Wspólnoty Niepodległych Państw, czego efektem stało się powołanie Synergii Czarnomorskiej, zainicjowanie wspólnej strategii wobec Azji Centralnej, poparcie - mimo początkowo pewnych wątpliwości - polsko-szwedzkiej idei Partnerstwa Wschodniego (2008), a nawet rozpoczęcie dyskusji wśród niemieckich elit politycznych na temat możliwości objęcia obszaru Kaukazu projektem stabilizacyjnym, zbliżonym w swojej koncepcji do założeń Paktu Stabilności dla Europy Południowo-Wschodniej ${ }^{31}$.

Wszystkie te wydarzenia powszechnie traktowano jako zapowiedź odejścia od dotychczasowej koncepcji zakładającej utrzymywanie i pogłębianie „strategicznego partnerstwa" z Rosją, jako priorytetowego celu niemieckiej polityki wschodniej, oraz równoległe do tego procesu rozwijanie, w dość ograniczonym zakresie i praktycznie wyłącznie $\mathrm{w}$ ramach UE, polityki wspierania transformacji społeczno-gospodarczej krajów postradzieckich, w tym zwłaszcza Ukrainy ${ }^{32}$.

Jak pokazał jednak rok 2009, ostatecznie nie doszło do znaczącego przewartościowania dotychczasowej polityki RFN wobec FR, a tym samym do zmiany niemieckiego stanowiska wobec euroatlantyckich aspiracji Ukrainy. Mimo widocznego pogorszenia relacji niemiecko-rosyjskich na początku 2009 r., dość szybko doszło bowiem do ich ponownej normalizacji i racjonalizacji zarazem, co potwierdził szczyt rosyjsko-niemiecki w Soczi (14 VIII 2009). W naturalny sposób ugruntowało to sceptyczne podejście Berlina do kwestii rozszerzenia NATO o Ukrainę, które zostało zarysowane w Bukareszcie, i przekonanie o zasadności podjętej wówczas decyzji. Co więcej, z czasem zagadnienie to - w obliczu zmieniającej się sytuacji politycznej na Ukrainie i pogłębiających się procesów integracyjnych na obszarze postradzieckim - niejako samoczynnie przestało być tematem przewodnim relacji niemiecko-ukraińskich, mimo iż formalnie RFN nadal odwoływała się w swojej polityce wobec Kijowa do koncepcji „otwartych drzwi" ${ }^{33}$.

Rok 2010 przyniósł praktyczne zamrożenie dyskusji nad euroatlantycką perspektywą Ukrainy. Fakt ten wynikał z dwóch przesłanek. Po pierwsze, nieprzy-

${ }^{30}$ C. Ochmann, Zbliżenie poprzez powiązania, „Dialog. Magazyn Polsko-Niemiecki” 2006, nr 76, s. 70-71.

${ }^{31}$ Relacje gospodarcze Niemiec z krajami Europy Środkowo-Wschodniej, Ośrodek Studiów Wschodnich, wrzesień 2008, s. 48.

${ }^{32}$ S. MEISTER, Niemiecki szpagat, s. 52.

${ }^{33}$ O.I. Shapovolova, Ukrajina v systemi dvostronnih vidnosyn is providnymi evropejskymi krajinamy, w: Zovnishnja polityka Ukrajiny - 2009: Strategithni ocinky, prognozy ta priorytety, red. G.M. Perepelyci, Kyjiv 2010, s. 272. 
znanie MAP Gruzji i Ukrainie w obliczu wojny gruzińsko-rosyjskiej co prawda uchroniło NATO przed utratą wiarygodności w sensie militarnym, ale nie w sensie politycznym. Sytuacja ta wzmocniła bowiem pozycję Rosji jako najważniejszego „centrum przyciągania” na obszarze postradzieckim, dając jej sygnał do zintensyfikowanych działań na rzecz wzmocnienia pozycji „,monopolisty” w procesie politycznej, ekonomicznej i militarnej integracji na obszarze byłego ZSRR. Jednocześnie ugruntowała zasadność postrzegania Rosji bądź to jako jedynego gwaranta stabilności obszaru postradzieckiego, bądź to jako głównego źródła jego destrukcji. Po drugie, wygranie wyborów prezydenckich przez Wiktora Janukowycza dość szybko zaowocowało zbliżeniem Ukrainy i Rosji (umowy charkowskie, 21 IV 2010) oraz faktycznym powrotem Kijowa do statusu państwa pozablokowego (2010), który został potwierdzony w Strategii Bezpieczeństwa Narodowego oraz w Doktrynie Wojennej w 2012 r. Spowodowało to zapoczątkowany jeszcze w 2008 r. nieoficjalny odwrót elit politycznych Ukrainy od idei integracji z NATO i ostateczne porzucenie koncepcji członkostwa w Sojuszu Północnoatlantyckim, jak również zamrożenie współpracy z nim, która została sprowadzona do niezbędnego minimum. Odzwierciedleniem tego rodzaju stanu rzeczy był również spadek i tak już niskiego poparcia dla członkostwa Ukrainy w NATO wśród społeczeństwa ukraińskiego ${ }^{34}$, powrót do geostrategicznego dryfu, powszechnie nazywanego ,polityką wielowektorowości” (tym razem jednak z wyraźnie przeniesionym punktem ciężkości na zacieśnianie relacji z Moskwą), i wreszcie traktowanie, niezależnie od sprawującej w danym momencie władzę elity rządzącej, kwestii członkostwa, czy nawet tylko współpracy z Sojuszem, jako instrumentu doraźnej walki politycznej, nie zaś mechanizmu konsolidującego wysiłek państwa i społeczeństwa, obliczony na osiągnięcie priorytetowego celu. Świadczyć o tym może choćby to, iż praktycznie żadna z partii ukraińskich (także opozycyjnych), poza mało znaczącą Ukraińską Partią "Zjednoczenie" (,Sobor”), w wyborach parlamentarnych w 2012 r. nie odniosła się wprost i jednoznacznie do tej idei ${ }^{35}$.

\footnotetext{
${ }^{34}$ Poparcie dla wstąpienia Ukrainy do NATO aż do 2014 r. nigdy nie osiągnęło poziomu większego niż 30\%. Z reguły oscylowało ono wokół poziomu 20\%. Przykładowo w 2012 r. członkostwo w Sojuszu cieszy się poparciem około 11-13\% społeczeństwa ukraińskiego. Dla porównania: wstąpienie do Organizacji Układu o Bezpieczeństwie Zbiorowym popierało wówczas około $20 \%$ obywateli. Faktem jest jednak widoczny spadek procentowy liczby osób upatrujących w NATO zagrożenia dla państwa ukraińskiego. O ile w 2006 r. aż 36,9\% Ukraińców upatrywało w Sojuszu potencjalnego wroga, o tyle w 2012 r. liczba ta osiągnęła poziom 22,2\%. Zob. szerzej: Badania socjologiczne przeprowadzone przez Ukrainskie Centrum Badań Ekonomicznych i Politycznych im. Oteksandra Razumkowa, http://www.razumkov.org.ua/ukr/socpolls.php?cat_id=49 [dostęp: 10.06.2018].

${ }^{35}$ Wywiad z dyrektorem Instytutu Polityki Zagranicznej Akademii Dyplomatycznej Ukrainy przy Ministerstwie Spraw Zagranicznych Ukrainy - profesorem Hryhorijem Perepełycją, przeprowadzony w dniu 17 X 2012 r. w Kijowie; zapis w posiadaniu autora.
} 
Powyższa sytuacja, wskazująca na permanentną niestabilność Ukrainy i zwiększony potencjał ryzyka pojawiający się $\mathrm{w}$ działaniach prowadzonych przez NATO, a także UE wobec obszaru postradzieckiego, ugruntowała w rządzącej od 2009 r. koalicji CDU/CSU/FDP przekonanie o zasadności przyjętej dotychczas jednoznacznie negatywnej postawy wobec euroatlantyckich dążeń Ukrainy. Mimo iż wojna w Gruzji ponownie unaoczniła Berlinowi zakres interesów Moskwy (zarówno w kontekście wynikających z nich celów, jak i w rozumieniu stricte geograficznym) oraz radykalność instrumentów stosowanych dla ich „obrony”, to jednak paradoksalnie w dalszym ciągu polityka niemiecka ukierunkowana była na postrzeganie Rosji bardziej jako „nieodzownego partnera” w przezwyciężaniu globalnych zagrożeń niż jako „nieprzewidywalnego sprawcę" ich zaistnienia w wymiarze regionalnym ${ }^{36}$. Konflikt na Kaukazie uzmysłowił władzom niemieckim, iż dotychczasowe mechanizmy współpracy z FR w sferze bezpieczeństwa, na przykład Rada Rosja-NATO, są nie do końca wystarczające, bowiem nie stały się one płaszczyzną dialogu na temat narastającego kryzysu gruzińsko-rosyjskiego i sposobów jego przezwyciężenia. Budowało to we władzach niemieckich przekonanie, iż proces rozwiązywania problemów na obszarze byłego ZSRR (m.in. „Zamrożone konflikty”) musi być realizowany paralelnie z działaniem na rzecz dalszego zacieśniania współpracy w zakresie europejskiego bezpieczeństwa, głównie opartego na UE i NATO, zgodnie ze strategią maksymalnego „włączania” i „oplątywania” Moskwy systemem euroatlantyckich norm, instrumentów i zobowiązań, przy jednoczesnym uwzględnianiu jej pozycji i znaczenia w Europie. Tego rodzaju przykłady, jak wyraźny wzrost zaangażowania władz niemieckich w rozwiązanie „zamrożonych konfliktów” na Kaukazie, a przede wszystkim w Naddniestrzu (w ramach procesu $5+2$ ), przy jednoczesnym rozwijaniu współdziałania w tym zakresie z Rosją (m.in. Inicjatywa z Meseberga, 4-5 VI 2010), wskazują na zasadność tej tezy. Świadomość, iż bez akceptacji Moskwy żadne działanie na obszarze postradzieckim nie przyniesie pozytywnych skutków, w naturalny sposób wymuszało na władzach niemieckich odpowiednią aktywność, obliczoną na poszerzenie instytucjonalnych i pozainsty-

\footnotetext{
${ }^{36}$ Rolę Rosji, jako partnera NATO w procesie rozwiązywania problemów światowego bezpieczeństwa, jednoznacznie ujął minister obrony w rządzie CDU/CSU/FDP - Karl-Theodor zu Guttenberg. Podczas swojego wystąpienia w Monachium w dniu 9 II 2010 r., w czasie corocznej konferencji poświęconej bezpieczeństwu, stwierdził on: „Żadnego dużego problemu, o którym dyskutujemy w ramach sojuszu, nie możemy bez Rosji rozwiązać: problemu Afganistanu i Pakistanu, Iranu, jak również kontroli zbrojeń i rozbrojenia, walki z terroryzmem i proliferacji”; Rede von Bundesverteidigungsminister Theodor zu Guttenberg auf der 46. Münchner Sicherheitskonferenz im Februar 2010 in München, http://www.polifo.de/uploads/568_Neues_strategisches_Konzept_der_NATO.pdf
} 
tucjonalnych form współpracy UE i NATO z FR ${ }^{37}$. Tego rodzaju podejście określiło również priorytety niemieckiej polityki wobec Kijowa, którą można opisać zasadą „maksimum reform, minimum problemów”. Odpowiednio do tego celem Berlina stało się uniknięcie możliwości pojawienia się trzech negatywnych sytuacji, w których: Ukraina stałaby się obszarem rywalizacji szeroko rozumianego Zachodu z Rosją; doszłoby do istotnych kryzysów i konfliktów w relacjach rosyjsko-ukraińskich; na terenie postradzieckim - mimo uwzględnienia rosyjskich interesów - nastąpiłaby swoista monopolizacja wpływów Moskwy ${ }^{38}$.

W ten ostatni wątek wpisuje się zresztą postulat kanclerz Merkel, przedstawiony jeszcze przed szczytem NATO w Lizbonie (19-20 X 2010), zgodnie z którym państwa neutralne oraz „pozablokowe” miały zostać objęte odrębnym porozumieniem o współpracy, które znalazłoby swoje odzwierciedlenie w nowej koncepcji strategicznej Sojuszu. Można więc uznać, iż możliwości uniknięcia monopolizacji wpływów rosyjskich na Ukrainie, w warunkach zdjęcia problematyki rozszerzenia NATO na Wschód z porządku dnia, Berlin upatrywał mimo wszystko w utrzymaniu kooperatywnych powiązań między tym krajem a Sojuszem Północnoatlantyckim, odpowiadających interesom obu stron ${ }^{39}$. W naturalny sposób wątpliwości budziła potencjalna skuteczność tego rodzaju działań, tym bardziej że zapisy szczytu w Lizbonie oraz nowej koncepcji strategicznej Sojuszu Północnoatlantyckiego jednoznacznie potwierdziły skoncentrowanie się paktu na obszarze „europejskich peryferii”, rozumianych jako obszar pozaeuropejski, o potencjalnym wysokim ryzyku pojawienia się sytuacji kryzysowych, rzutujących bezpośrednio na stabilność euroatlantycką. Znalazło to odzwierciedlenie w koncepcji ,dalekich partnerstw” ${ }^{40}$. Tego rodzaju formuła w sposób formalny nie zastąpiła koncepcji „rozszerzenia” NATO, ale wskazywała na dominujący wówczas sposób myślenia sojuszu o strategicznych wyzwaniach i zagrożeniach przed nim stojących, generowanych obecnie przede wszystkim na obszarach pozaeuropejskich ${ }^{41}$. Tym samym współdziałanie z Rosją w procesie utrzymania stanu „zamrożenia” konfliktów na obszarze postradzieckim oraz przy rozwiązy-

\footnotetext{
${ }^{37}$ Niemcy i Rosja o bezpieczeństwie, „Tydzień na Wschodzie”. Ośrodek Studiów Wschodnich 2010, nr 20, s. 10.

38 O.I. SHAPOvolova, Ukrajina $v$ systemi dvostronnih vidnosyn is providnymi evropejskymi krajinamy, w: Zovnishnja polityka Ukrajiny - 2009: Strategithni ocinky, prognozy ta priorytety, red. G.M. Perepelyci, Kyjiv 2011, s. 267.

39 Tamże, s. 268.

${ }^{40}$ Koncepcja strategiczna obrony i bezpieczeństwa członków Organizacji Traktatu Pótnocnoatlantyckiego, przyjęta przez szefów państw i rządów w Lizbonie, 19-20 XI 2010, Biuro Bezpieczeństwa Narodowego, http://www.bbn.gov.pl/portal/pl/2/2694/Koncepcja_Strategiczna_NATO_tlu maczenie.html [dostęp: 17.06.2018].

${ }^{41}$ Tamże; P. PACUŁA, Przyszłość polityki ,otwartych drzwi” NATO, „Bezpieczeństwo Narodowe" 2012, nr 1 (21), s. 99.
} 
waniu sytuacji kryzysowych na obszarze Północnej Afryki, Bliskiego i Środkowego Wschodu wydawało się ważniejsze niż praktyczne wdrażanie idei „otwartych drzwi", konfrontujących Sojusz z Moskwą i narażających go na konieczność praktycznego potwierdzania swojej „wiarygodności” jako systemu kolektywnej obrony ${ }^{42}$.

W tym szerokim politycznym kontekście, który nakreśliły wydarzenia mające miejsce w latach 2010-2012, komunikat końcowy szczytu w Bukareszcie w 2008 r., potwierdzający przyszłe - nieskonkretyzowane w sensie formalnym, proceduralnym i czasowym - członkostwo Ukrainy i Gruzji w NATO, jak również podobnego rodzaju wypowiedzi kanclerz Merkel z okresu wojny rosyjsko-gruzińskiej, można było postrzegać już tylko jako wydarzenie o znaczeniu historycznym, nie zaś rzeczywisty paradygmat, którym mógł i chciał kierować się Sojusz Północnoatlantycki. Tego rodzaju sytuację, ale tylko w pewnym zakresie, zmieniły dopiero wydarzenia związane z tzw. rewolucją godności (2013/2014), których konsekwencją było odsunięcie od władzy urzędującego prezydenta Wiktora Janukowycza, okupacja i aneksja Krymu przez wojska rosyjskie oraz powstanie separatystycznych „tworów” w postaci Donieckiej Republiki Ludowej i Ługańskiej Republiki Ludowej, wspieranych i kontrolowanych - bardziej lub mniej otwarcie - przez FR.

Rosyjsko-ukraiński konflikt zbrojny w całej swojej rozciągłości odzwierciedla główne problemy i dylematy stojące obecnie przed relacjami niemiecko-ukraińskimi, których jednym z najważniejszych aspektów nadal pozostaje problem rozszerzenia NATO o Ukrainę. Biorąc to pod uwagę można stwierdzić, iż sposób podejścia do tej kwestii Berlina i Kijowa jest nadal diametralnie różny, co zasadniczo wynika z przyjęcia przeciwstawnych założeń. Na dany moment nie ulega wątpliwości, iż obecnie główny wysiłek obu państw, określający dynamikę wzajemnych relacji, skoncentrowany jest na kwestii utrzymania integralności terytorialnej Ukrainy i zakończenia toczącego się tam konfliktu zbrojnego. O ile jednak nowa władza w Kijowie, mimo początkowej ostrożności, dość szybko zdefiniowała swój euroatlantycki wybór, upatrując w nim szansę na przezwyciężenie konfliktu i wzmocnienie swojego potencjału obronnego, a przede wszystkim na uzyskanie w dalekiej przyszłości gwarancji bezpieczeństwa ${ }^{43}$, o tyle ko-

${ }^{42}$ G. FRIEDMAn, Nastęna dekada. Gdzie byliśmy i dokąd zmierzamy, Kraków: Wydawnictwo Literackie 2012, s. 157.

43 Zob. Ukraina chce do NATO. Zmiana polityki, 8 VI 2017, Defence24, https://www. defence24.pl/ukraina-chce-do-nato-zmiana-polityki [dostęp: 16.06.2018]; NATO priorytetem Ukrainy. Specjalna uchwała parlamentu, 8 VI 2017, PAP, cyt. za: Polskie Radio, https://www.pol skieradio.pl/5/3/Artykul/1774762,NATO-priorytetem-Ukrainy-Specjalna-uchwala-parlamentu [dostęp: 17.06.2018]. 
lejny rząd „wielkiej koalicji” (2013-2017) w sposób zdecydowany odrzucał tego rodzaju podejście, uznając je za zagrażające podejmowanym wysiłkom na rzecz pokojowego zakończenia konfliktu.

W niemieckiej strategii przyjętej w sytuacji rosyjskiej agresji na Ukrainę wyraźnie widoczny jest prymat środków dyplomatycznych nad wojskowymi. W praktyce oznacza to dążenie do uniknięcia możliwości zaostrzenia sytuacji w wyniku działań podejmowanych przez NATO, lub też przez jego poszczególnych członków, w szeroko rozumianej sferze militarnej, na którą składają się zarówno przedsięwzięcia służące zwiększeniu potencjału odstraszania członków paktu, jak i te - podejmowane indywidualnie - służące wzmocnieniu potencjału obronnego państwa ukraińskiego. Uznaje się bowiem, że wszelkie działania realizowane w tym obszarze mogą zaogniać sytuację w obszarze bezpieczeństwa i ograniczać pole manewru dla dyplomacji niemieckiej, która w sposób niepodważalny odgrywa w procesie przezwyciężania konfliktu dominującą rolę ${ }^{44}$. Jest to nie tylko konsekwencja wciąż istniejących „specjalnych stosunków” między Rosją i RFN czy też bezpośredniego zaangażowania w rozwiązywanie konfliktu kanclerz Merkel i wcześniej ministra Steinmeiera, ale również akceptacji tego rodzaju aktywności przez państwa europejskie, z Ukrainą włącznie.

Nie ulega wątpliwości, iż punkt ciężkości rozważań na temat skuteczności i możliwości realizacji przez RFN polityki przezwyciężania konfliktu zbrojnego na Ukrainie skupia się wokół kwestii Rosji i jej swoistej podwójnej roli, jaką odgrywa ona $\mathrm{w}$ sferze międzynarodowego bezpieczeństwa. $\mathrm{Z}$ jednej strony jest ona bowiem siłą generującą konflikty (a nawet mniej lub bardziej otwarte wojny), przyjmującą rolę uczestniczącej w niej strony (przy czym oficjalnie nie potwierdza tego rodzaju stanu rzeczy), z drugiej zaś stanowi podmiot nieodzowny dla ich rozwiązania. Tego rodzaju sytuacja jest powszechnie znana, ale realnie nie ma możliwości jej zmiany, co w dużej mierze wiąże się zarówno z silną pozycją międzynarodową FR, jak i ze zdolnością władz rosyjskich do „elastycznego" i zarazem „twardego” zarządzania konfliktami, odpowiednio do swoich trwałych interesów. W konsekwencji nie tylko Niemcy, ale także większość społeczności międzynarodowej pozostaje w sytuacji ograniczonej możliwości oddziaływania na Rosję. Całościowo skutkuje to przekonaniem, iż niezależnie od stanu konfliktu na Ukrainie i roli, jaką odgrywa w nim Moskwa, budowanie długotrwałego, stabilnego ładu europejskiego może być realizowane zawsze z jej udziałem, nigdy zaś przeciw niej. Przy czym obecnie stawia się tu pewien warunek. Także sama FR musi zdefiniować swoje interesy wobec Europy, wyzbyć się

${ }^{44}$ Por. T. NOWAK, Odstraszanie i dialog - szczyt NATO z niemieckiej perspektywy, 10 VII 2016, Defence24, https://www.defence24.pl/odstraszanie-i-dialog-szczyt-nato-z-niemieckiej-perspektywy [dostęp: 12.06.2018]. 
traktowania jej w kategoriach przeciwnika czy nawet wroga i wreszcie określić, w jakim stopniu chce uczestniczyć wspólnie z innymi krajami w budowaniu systemu europejskiego bezpieczeństwa ${ }^{45}$.

Biorąc pod uwagę powyższe można stwierdzić, iż niemiecka polityka wobec FR realizowana jest w formule: „angażowania” opartego na instrumentach dyplomatycznych oraz ,powstrzymywania” opierającego się na mechanizmie sank$\mathrm{cji}^{46}$. Odpowiednio do tego działania niemieckie bazują głównie na instrumentach dyplomatycznych, a dopiero w przypadku braku ich skuteczności, spowodowanej taką czy inną postawą Moskwy, stosowane są sankcje. Warto jednak przy tym zwrócić uwagę, iż w tej sytuacji nawet proces nakładania na państwo rosyjskie różnego rodzaju sankcji nie jest traktowany jako cel sam w sobie ${ }^{47}$. Co więcej, uznaje się, że spowodowana tego typu działaniami ewentualna destabilizacja gospodarki rosyjskiej może doprowadzić wyłącznie do pogłębienia deficytu bezpieczeństwa na obszarze Europy Środkowej i Wschodniej ${ }^{48}$. W takiej sytuacji nadmierna liczba i intensywność przedsięwzięć podejmowanych przez NATO w sektorze militarnego bezpieczeństwa lub też do niego się odnoszących są z natury postrzegane przez Berlin jako wydarzenia potencjalnie zagrażające procesowi transformacji konfliktu na Ukrainie, jak i ogólnie europejskiemu bezpieczeństwu.

Patrząc całościowo można stwierdzić, iż stanowisko Niemiec wobec ukraińskich aspiracji w obszarze euroatlantyckiej integracji w dużej mierze wpisuje się w decyzje przyjęte podczas szczytów Sojuszu Północnoatlantyckiego w Newport (4-5 IX 2014) i w Warszawie (8-9 VII 2016), które nie nakreśliły przed Ukrainą realnej perspektywy członkostwa ${ }^{49}$. Odpowiednio do nich Berlin pozostaje na stanowisku, iż kwestia rozszerzenia obecnie znajduje się poza agendą NATO. Uwzględnianie w tym zakresie postulatów Kijowa byłoby działaniem powodującym wzrost napięć i eskalację konfliktu. Jednocześnie, uznając prawo Ukrainy do swobodnego wyboru sojuszy, odrzuca się zasadę automatyczności w akcepta-

${ }^{45}$ Rede von Außenminister Steinmeier bei der Münchner Sicherheitskonferenz 2015, 8 II 2015, Auswärtiges Amt, www.auswaertiges-amt.de/DE/Infoservice/Presse/Reden/2015/150208_BM_M \%C3\%BCSiKo.html [dostęp: 13.06.2018].

46 A. KwiatKowsKa-DrożDż, K. FYMARK, Deutschland im Russland-Ukraine-Konflikt: eine politische oder eine humanitäre Aufgabe?, „Ukraine-Analysen”, 24 III 2015, nr 148, s. 3.

47 Pressestatements von Bundeskanzlerin Merkel und dem ukrainischen Präsidenten Poroschenko in Berlin, 16 III 2015, Bundeskanzlerin, www.bundeskanzlerin.de/Content/DE/Mitschrift/ Pressekonferenzen/2015/03/215-03-16-merkel-poroschenko.html [dostęp: 18.06.2018].

48 Steinmeier hat Hoffnung auf Ukraine-Gipfel nicht aufgegeben, 15 I 2015, „Die Welt”, www.welt.de/print/die_welt/wirtschaft/article136385771/Steinmeier-hat-Hoffnung-auf-UkraineGipfel-nicht-aufgegeben.html [dostęp: 17.06.2018].

49 Zob. A. TURKowski, Ukraina i NATO: granice integracji, 12 VII 2016, Defence24, https://www.defence24.pl/ukraina-i-nato-granice-integracji [dostęp: 23.06.2018]. 
cji stanowisk państw deklarujących chęć uzyskania członkostwa w pakcie, nie uwzględniającej szerszego kontekstu politycznego czy też międzynarodowego. W przypadku Ukrainy wskazuje się, iż kraj ten nie spełnia wielu podstawowych kryteriów członkostwa i rozpoczęcie procesu jego integracji z NATO w sytuacji trwającego konfliktu z Rosją jest bezzasadne. Z natury rzeczy postuluje się poszerzenie płaszczyzny współpracy NATO z Ukrainą oraz rozszerzenie programów wsparcia dla reformy jej sektora bezpieczeństwa, nie powinno to jednak oznaczać możliwości przyznania jej jakichkolwiek gwarancji bezpieczeństwa lub też nadania MAP czy też statusu głównego sojusznika spoza NATO (Major non-NATO Ally, MNNA). W ten sposób potwierdzony jest prymat w polityce niemieckiej ogólnej zasady „otwartych drzwi” nad praktycznym, ukierunkowanym podmiotowo podejściem do proatlantyckich dążeń poszczególnych państw ${ }^{50}$.

Ponadto, mając na względzie dążenie do unikania budowania napięć w relacjach z FR, Berlin uznał, iż proces dostarczania broni na Ukrainę w warunkach działań zbrojnych może odbywać się wyłącznie poza strukturami sojuszu, w oparciu o indywidualne decyzje poszczególnych państw członkowskich. Inaczej można byłoby bowiem stworzyć przekonanie, iż konflikt ten można rozwiązać militarnie ${ }^{51}$, nie zaś - co odpowiada koncepcji niemieckiej - za pomocą szerokich działań dyplomatycznych.

Patrząc na dotychczasowe działania władz niemieckich można stwierdzić, że ich aktywność ukierunkowana jest przede wszystkim na utrzymanie pola dialogu z Rosją. Tym samym głównym celem polityki niemieckiej jest ograniczenie zakresu konfliktu, zarówno w wymiarze jego dynamiki, jak i zasięgu terytorialnego, a następnie jego stopniowe wygaszenie. Dopiero później możliwe jest przynajmniej teoretycznie - osiągnięcie drugiego celu, a mianowicie powrotu do starych zasad i norm funkcjonowania ładu międzynarodowego, istniejących przed wybuchem konfliktu. Precyzując, oznacza to, iż niemiecka strategia wobec konfliktu na Ukrainie z założenia jest obliczona na osiągnięcie dwóch celów. Pierwszym z nich, rozpatrywanym w krótkim i średnim horyzoncie czasowym, jest transformacja konfliktu (jego deeskalacja i rozwiązanie) oraz zminimalizo-

\footnotetext{
${ }^{50}$ Zob. szerzej: M. MADEJ, Konflikt na Ukrainie - implikacje dla NATO i Polski, w: Implikacje konfliktu ukraińskiego dla polityki zagranicznej i bezpieczeństwa Polski. Aspekty polityczne, wojskowe, gospodarcze oraz społeczne, red. naukowa K. Czornik, M. Lakomy, M. Stolarczyk, Katowice 2016, s. 228-246; A. TURKOwSKI, Ukraina i NATO; zob. Deklaracja końcowa szczytu NATO w Warszawie wydana przez Szefów Państw i Rządów uczestniczących w posiedzeniu Rady Pólnocnoatlantyckiej w Warszawie w dniach 8 i 9 lipca 2016 r., „Bezpieczeństwo Narodowe” 2016, nr 1-4, s. 205-242.

${ }^{51}$ Niemcy przeciw zbrojeniu Ukrainy $i$ nie widza jej w NATO, PAP, cyt. za: Polskie Radio, 31 VIII 2014, https://www.polskieradio.pl/5/3/Artykul/1219801,Niemcy-przeciw-zbrojeniu-Ukra iny-i-nie-widza-jej-w-NATO [dostęp: 17.06.2018].
} 
wanie i neutralizacja (bądź wygaszenie) ,agresywnego” potencjału Rosji, wymierzonego w państwo ukraińskie. Drugim zaś, rozpatrywanym długofalowo, jest zintegrowanie Moskwy w ramach europejskiej architektury bezpieczeństwa, a w konsekwencji doprowadzenie do odbudowy i wzmocnienia ładu międzynarodowego, m.in. poprzez wzmocnienie pozycji Organizacji Narodów Zjednoczonych $^{52}$.

Jak pokazuje jednak rzeczywistość, RFN w swoich działaniach musi liczyć się z wieloma przeszkodami, które w sposób bezpośredni rzutują nie tylko na skuteczność stosowanych środków (dotyczy to zarówno mechanizmów prewencyjnych, jak i samych sankcji), ale przede wszystkim na ich małą ilość 53 . Ograniczone możliwości kreowania i stosowania mechanizmów prewencyjnych w warunkach konfliktu rosyjsko-ukraińskiego są wynikiem bardzo złożonych i skomplikowanych uwarunkowań, do których należy zaliczyć: a) ograniczone spektrum mechanizmów politycznego i pozapolitycznego oddziaływania na Rosję; b) podatność Niemiec na ,argumenty siły”54; c) określony przez Moskwę wysoki próg osiągania kompromisu; d) brak możliwości pełnego, międzynarodowego izolowania Rosji; e) różnice w łonie UE co do głównych założeń polityki wobec FR; f) wyraźnie prorosyjska postawa części niemieckich elit politycznych i gospodarczych $^{55}$.

Dodatkowym problemem dla niemieckiej dyplomacji jest konieczność unikania jednoznacznego zdefiniowania Rosji jako agresora, przy jednoczesnym uwzględnianiu jej pozycji jako czynnego uczestnika procesu negocjacyjnego.

${ }^{52}$ Rede von Außenminister Steinmeier bei der Münchner Sicherheitskonferenz 2015.

53 Obecnie można wymienić dwa główne mechanizmy oddziaływania Berlina na konflikt na wschodzie Ukrainy, a mianowicie: Format „Normandzki” („Czwórka Normandzka”) oraz system OBWE. Ponadto można do nich zaliczyć również wspomniany już wcześniej mechanizm sankcji, który jednak jako taki wykracza poza klasycznie rozumiane środki działań prewencyjno-dyplomatycznych.

${ }^{54}$ Zob. A. KwiatKowsKa-DrożDż, K. Fymark, Deutschland im Russland-Ukraine-Konflikt, s. 5.

55 Mowa tutaj przede wszystkim o SPD oraz Wschodniej Komisji Niemieckiej Gospodarki (Ost-Ausschus der Deutschen Wirtschaft, OADW), które domagały się wprost o ile nie pełnego zniesienia, to przynajmniej daleko idącego ograniczenia sankcji wobec Rosji i zaniechania prób jej międzynarodowego izolowania; Wir hätten uns mehr Mut gewünscht. Stellungnahme des OstAusschuss-Vorsitzenden Eckhard Cordes zur Verlängerung der Russland-Sanktionen, 17 XII 2015, Ost-Ausschus der Deutschen Wirtschaft, www.ost-ausschuss.de/node/1035 [dostęp: 15.06.2018]; Über wirtschaftliche Annaeherung zur politischen Verstaendigung. Grußwort von Eckhard Cordes beim Deutsch-Russischen Wirtschaftsdialog, 9 XI 2015, Ost-Ausschus der Deutschen Wirtschaft, www.ost-ausschuss.de/node/1007 (16 VI 2018); Gabriel wirbt für Aufhebung der Sanktionen gegen Russland, 25 IX 2015, „Süddeutsche Zeitung”, www.sueddeutsche.de/politik/moskaus-rolle-im-sy rien-krieg-gabriel-wirbt-fuer-aufhebung-der-sanktionen-gegen-russland-1.2666045 [dostęp: 17.06. 2018]; SPD-Politiker wollen Sanktionen gegen Putin beenden, 28 IX 2015, „Die Welt”, www.welt. de/politik/deutschland/article146952409/SPD-Politiker-wollen-Sanktionen-gegen-Putin-beenden.html [dostęp: 16.06.2018]. 
Jest to sytuacja o wiele trudniejsza z punktu widzenia stosowania środków przezwyciężania kryzysu niż w przypadku konfliktu w Naddniestrzu czy też nawet wojny rosyjsko-gruzińskiej ${ }^{56}$. Jeszcze innym problemem jest kwestia uniknięcia przez RFN swoistych politycznych ,pułapek”, kreowanych intensywnie przez stronę rosyjską. Tego rodzaju przykładem jest choćby próba przedstawienia „konfliktu o Ukrainę” jako przejawu rywalizacji czy też bezpośrednio konfliktu na linii USA-Europa. W tym kontekście Ukraina określana jest przez władze w Moskwie jako państwo pozostające pod pełnym wpływem i kontrolą Stanów Zjednoczonych, które poprzez swoje działania, przy poparciu niektórych krajów UE, jak np. Polski i Litwy, może doprowadzić do podziału kontynentu europejskiego i jego destabilizacji ${ }^{57}$. W naturalny sposób podział ten przekłada się również na sytuację w NATO, które - zgodnie ze stanowiskiem FR - jest w dużej mierze instrumentem realizacji polityki amerykańskiej. Różnice zdań między RFN i USA, istniejące i narosłe wokół np. kwestii wsparcia Ukrainy bronią defensywną, pokazują, iż pojawienie się na tym tle ewentualnych głębszych podziałów w Europie nie jest do końca niemożliwe ${ }^{58}$.

Także wspomniana wyżej podatność Niemiec na argumenty „siły” nie sprzyja skutecznemu osiąganiu określonych przez Berlin celów, jak również przyjęciu przez niego konstruktywnego podejścia do problemu rozszerzenia NATO na Wschód. W tego rodzaju sytuacji każdorazowo, gdy dochodzi do ponownego wybuchu lub zaostrzenia konfrontacji, zmniejsza się „twardość” władz niemieckich w stosunku do Rosji i zwiększa gotowość do kompromisu lub ustępstw. Potęguje się również strach przed podejmowaniem działań mogących zakłócić dotychczasowy proces ,wygaszenia” konfliktu. Konsekwencją tego rodzaju podejścia jest m.in. wspomniany już sprzeciw władz niemieckich wobec możliwości dostarczenia na Ukrainę broni defensywnej lub też naciski na ten kraj w sprawie jak najszybszego wprowadzenia zmian w konstytucji oraz przyjęcia ustawy o specjalnym statusie dla ,niektórych rejonów obwodów donieckiego i ługańskiego" 59 .

${ }^{56}$ Zob. szerzej: A. DRZEwICKI, Działania prewencyjne w polityce bezpieczeństwa Republiki Federalnej Niemiec na przyktadzie konfliktu zbrojnego na Ukrainie, w: Niemcy z polskiej pespektywy, red. K. Gelles, Wrocław 2016, s. 71-88, „Niemcoznawstwo”, t. XXIV.

57 Zob. Wywiad z Prezydentem Federacji Rosyjskiej Władimirem Putinem, przeprowadzony 17 XII 2015 r., wyemitowany w ramach filmu dokumentalnego Miroporjadok, autor: Władimir Sołowjow, Kanał: Rossija 1, data emisji: 20 XII 2015, www.youtube.com/watch?v=ZNhYzYUo42g [dostęp: 16.06.2018].

58 Por. C. MAJOR, CH. MoElling, Zwischen Krisen und Verantwortung: Eine erste Bilanz der neuen deutschen Verteidigungspolitik, XII 2015, Note du Cerfa 127, Studienkomitee für deutschfranzösische Beziehungen (Cerfa).

${ }^{59}$ K. SCHULLER, Westliche Einflussnahme. Der Albtraum ukrainischer Politiker, „Frankfurter Allgemeine Zeitung", 17 VIII 2015. 
Jak widać, w przekonaniu Berlina warunkiem wstępnym powodzenia wymienionych działań jest całościowa deeskalacja sytuacji i unikanie napięć, zarówno w ramach konfliktu, jak i wokół niego, a więc co za tym idzie - także prowadzenia realnej dyskusji nad euroatlantycką perspektywą Ukrainy. W tym kontekście naturalnym zabiegiem Berlina staje się dążenie do trwałego zdjęcia z międzynarodowej agendy kwestii przystąpienia Ukrainy do NATO lub przynajmniej do jej trwałego „zamrożenia”.

Zakres i intensywność współpracy Niemiec z Ukrainą, mimo dużych oczekiwań i nadziei wyrażanych przede wszystkim przez stronę ukraińską, przedstawiały się $\mathrm{w}$ omawianych latach raczej dość skromnie. Władze niemieckie nie tylko nie wypracowały w tym okresie jasno sprecyzowanej koncepcji politycznej wobec tego kraju, ale stały się nawet jednym z głównych zwolenników realizacji zasady Russia First. Zgodnie z nią polityka rządów państw zachodnich wobec Kijowa, zarówno w relacjach bilateralnych, jak i wielostronnych, miała być przede wszystkim determinowana stanowiskiem Rosji, a także stanem współpracy rosyjsko-ukraińskiej. Wynikało to głównie z faktu, iż Moskwa była postrzegana najpierw jako jedyna siła na terenie byłego ZSRR, zdolna zagwarantować stabilność i bezpieczeństwo tego obszaru, potem zaś jako nieodzowny „sojusznik" w procesie przezwyciężania zagrożeń o charakterze globalnym. W sposób naturalny rzutowało to na podejście Berlina do wyrażanych przez Kijów, począwszy od 2002 r., euroatlantyckich aspiracji. Postawa władz niemieckich względem postulatów dotyczących członkostwa Ukrainy w NATO była niezmiennie negatywna, zaś zakres argumentacji używanej dla uzasadnienia własnego stanowiska, niezależnie od sytuacji międzynarodowej oraz rozwoju sytuacji politycznej i społeczno-ekonomicznej w państwie ukraińskim, miał zasadniczo charakter stały. Dominowały argumenty mówiące o permanentnej niestabilności Ukrainy, niedojrzałości elit tego państwa, niskim poparciu dla idei członkostwa wśród ukraińskiego społeczeństwa, kreowaniu kolejnych źródeł zagrożeń na obszarze postradzieckim oraz nieakceptowalnym izolowaniu Rosji.

W zasadniczy sposób tego rodzaju podejścia nie zmienił nawet proces odchodzenia przez Niemcy od zasady Russia First, którego pierwsze symptomy można zauważyć w 2005 r., ani wydarzenia związane $\mathrm{z}$ wojną rosyjsko-gruzińską w 2008 r. i rosyjsko-ukraińskim kryzysem gazowym w 2009 r., które w sposób istotny podważyły zaufanie RFN do Moskwy. Sytuacja ta zaowocowała jedynie wysoce deklaratywnymi wypowiedziami kanclerz Niemiec Angeli 
Merkel o realnej możliwości przystąpienia Ukrainy i Gruzji do NATO. Był to poniekąd głos sprzeciwu wobec radykalnych tendencji w polityce zagranicznej FR, za którym nie poszły jednak realne działania, zarówno ze strony Berlina, jak i Kijowa. W tym kontekście doszło jednak do zmiany narracji w określaniu zasadności realizacji procesu rozszerzenia Paktu o Ukrainę. Odtąd w wypowiedziach polityków niemieckich zaczęła dominować argumentacja odwołująca się do zasady „otwartych drzwi”, która zasadniczo nie podważała możliwości uzyskania przez Kijów członkostwa w NATO w bliżej nieokreślonym czasie, ale negowała automatyczność i obligatoryjność podejmowania działań w stosunku do wszystkich państw deklarujących chęć przystąpienia do paktu, nawet jeśli z obiektywnych przyczyn nie spełniają one politycznych i militarnych kryteriów przynależności.

Podczas trwającego od 2014 r. rosyjsko-ukraińskiego konfliktu zbrojnego Ukraina nie doczekała się zarysowania jasnej perspektywy członkostwa. Co więcej, w istniejącej sytuacji kwestia ta traktowana jest jako czynnik budujący dodatkowe napięcia i tym samym uniemożliwiający dyplomatyczne przezwyciężenie kryzysu. Tego rodzaju podejście, w warunkach prawdopodobnej permanentności konfliktu, oznacza nie tylko realne zdjęcie kwestii rozszerzenia Sojuszu na Wschód z euroatlantyckiej agendy, ale prawdopodobnie również długotrwałe jej „zamrożenie”.

\section{BIBLIOGRAFIA}

Buhbe M., Grundzüge einer deutsche Russland-Strategie, w: Deutschland in den internationalen Beziehungen. Ziele, Instrumente, Perspektiven, III 2007, Bonn-Berlin: Freidrich Ebert Stiftung 2007, s. 8.

Drzewicki A., Działania prewencyjne w polityce bezpieczeństwa Republiki Federalnej Niemiec na przykładzie konfliktu zbrojnego na Ukrainie, w: Niemcy z polskiej pespektywy, red. K. Gelles, Wrocław 2016, s. 71-88, „Niemcoznawstwo”, t. 24.

DrZewICKi A., Europa Środkowa i Wschodnia w polityce bezpieczeństwa Republiki Federalnej Niemiec 1990-1998. Stanowisko niemieckich partii politycznych, Toruń: Wyd. Adam Marszałek 2010.

Drzewicki A., Europejska Polityka Wschodnia - doświadczenia i wnioski dla Polski, „Przegląd Zachodni" 2011, nr 3, s. 45-65.

Friedman G., Następna dekada. Gdzie byliśmy i dokąd zmierzamy, Kraków: Wydawnictwo Literackie 2012.

JUNG F.J., Streitkräfte als Instrument einer umfassenden, vernetzen Sicherheits- und Verteidigungspolitik, w: Sicherheitspolitik in neuen Dimensionen, Hamburg-Berlin-Bonn: Bundesakademie für Sicherheitspolitik 2009, s. 42.

KNÜPLING F., Od Bałkanów do Hindukuszu. Czerwono-zielona polityka zagraniczna przed nowymi wyzwaniami, „Dialog. Magazyn Polsko-Niemiecki” 2005, nr 69-70, s. 25.

KonTRATJUK S.V., Evropejska polityka objednanoji Nimeththyny, Kyjiv 2008, s. 191-202. 
KUDRJATHENKO A.I., Ukrajinsko-nimecki vidnosyny v konteksti globalnyh zrushen na kontynenti, w: Ukrajina v Evropi: poshuky spilnoho majbutnoho, Kyjiv 2009, s. 204.

KwiatKowsKA-DrożDż A., FYMARK K., Deutschland im Russland-Ukraine-Konflikt: eine politische oder eine humanitäre Aufgabe?, „Ukraine-Analysen”, 24 III 2015, nr 148, s. 3.

MAdeJ M., Konflikt na Ukrainie - implikacje dla NATO i Polski, w: Implikacje konfliktu ukraińskiego dla polityki zagranicznej i bezpieczeństwa Polski. Aspekty polityczne, wojskowe, gospodarcze oraz społeczne, red. naukowa K. Czornik, M. Lakomy, M. Stolarczyk, Katowice 2016, s. 228-246.

Major C., Moelling CH., Zwischen Krisen und Verantwortung: Eine erste Bilanz der neuen deutschen Verteidigungspolitik, XII 2015, Note du Cerfa 127, Studienkomitee für deutschfranzösische Beziehungen (Cerfa).

MANZHOŁA V.A., Ukrajina v systemi dvostronnih vidnosyn is providnymi evropejskymi krajinamy, w: Zovnishnja polityka Ukrajiny - 2008: Strategithni ocinky, prognozy ta priorytety, red. G.M. Perepelyci, Kyjiv 2009, s. 273-274.

MeISTER S., Niemiecki szpagat, „Nowa Europa Wschodnia” 2009, nr 2, s. 50.

Niemcy i Rosja o bezpieczeństwie, „Tydzień na Wschodzie”. Ośrodek Studiów Wschodnich 2010, nr 20, s. 10.

OChmann C., Zbliżenie poprzez powiązania, „Dialog. Magazyn Polsko-Niemiecki” 2006, nr 76, s. $70-71$.

PacuŁa P., Przyszłość polityki „otwartych drzwi” NATO, „Bezpieczeństwo Narodowe” 2012, nr 1(21), s. 99.

PIETRAŚ M., Stosunki Ukrainy z Sojuszem Północnoatlantyckim, w: Ukraina w stosunkach międzynarodowych, red. M. Pietraś, T. Kapuśniak, Lublin: Wydawnictwo UMSC 2007, s. 360-365.

Relacje gospodarcze Niemiec z krajami Europy Środkowo-Wschodniej, Raport, Ośrodek Studiów Wschodnich, 15.09.2008.

SCHWALL-Düren A., Polacy i Niemcy - partnerzy w kształtowaniu aktywnej polityki wschodniej? Wykład ku czci Willy Brandta, XII 2006 r., Warszawa: Fundacja im. Friedricha Eberta 2006, s. $19-20$

SedLmaYr S., Die aktive Aussen- und Sicherheitspolitik der rot-grünen Bundesregierung 19982005, Wiesbaden 2008, s. 133-140.

SHAPOVOLOVA O.I., Ukrajina $\mathrm{v}$ systemi dvostronnih vidnosyn is providnymi evropejskymi krajinamy, w: Zovnishnja polityka Ukrajiny - 2009: Strategithni ocinky, prognozy ta priorytety, red. G.M. Perepelyci, Kyjiv 2010, s. 272.

SHAPOVOLOVA O.I., Ukrajina v systemi dvostronnih vidnosyn is providnymi evropejskymi krajinamy, w: Zovnishnja polityka Ukrajiny - 2010: Strategithni ocinky, prognozy ta priorytety, red. G M. Perepelyci, Kyjiv 2011, s. 267.

Stosunki Rosja-Niemcy w latach 1998-2005, Raport OSW/CSM, Warszawa, II 2006.

Trener J., Berlin - Moskwa: nowy rzeczowy styl Niemców?, „Dialog. Magazyn Polsko-Niemiecki” 2007, nr 77-78, s. 62-66.

ŻERKO S., Niemcy wobec konfliktu w Gruzji (sierpień 2008 r.), „Biuletyn Instytutu Zachodniego” 2008 , nr 1 .

\section{Dokumenty}

Antrag der Abgeordneten Claudia Nolte, Dr. Friedbert Pflüger, Peter Hintze, weiterer Abgeordneter und der Fraktion der CDU/CSU: Für eine klare europäische Perspektive der Ukraine, Plenarprotokoll 15/178, Deutscher Bundestag, 2 VI 2005. 
CDU/CSU, Deutschlands Chancen nutzen. Wachstum, Arbeit, Sicherheit. Regierungsprogramm 2005-2009, Berlin 11 VII 2005, www.cdu.de/doc/pdfc/05_07_11_Regierungsprogramm.pdf

Deklaracja końcowa szczytu NATO w Warszawie wydana przez Szefów Państw i Rządów uczestniczących w posiedzeniu Rady Północnoatlantyckiej w Warszawie w dniach 8 i 9 lipca 2016 r., „Bezpieczeństwo Narodowe” 2016, nr 1-4, s. 205-242.

Gemeinsam für Deutschland. Mit Mut und Menschlichkeit. Koalitionsvertrag zwischen der CDU, CSU und SPD, Berlin 2005.

Koncepcja strategiczna obrony i bezpieczeństwa członków Organizacji Traktatu Północnoatlantyckiego przyjęta przez szefów państw i rządów w Lizbonie, 19-20 XI 2010, Biuro Bezpieczeństwa Narodowego, http://www.bbn.gov.pl/portal/pl/2/2694/Koncepcja_Strategicz na_NATO_tlumaczenie.html

Pressestatements von Bundeskanzlerin Merkel und dem ukrainischen Präsidenten Poroschenko in Berlin, 16 III 2015, Bundeskanzlerin, www.bundeskanzlerin.de/Content/DE/Mitschrift/Presse konferenzen/2015/03/215-03-16-merkel-poroschenko.html

Rede von Außenminister Steinmeier bei der Münchner Sicherheitskonferenz 2015, 8 II 2015, Auswärtiges Amt, www.auswaertiges-amt.de/DE/Infoservice/Presse/Reden/2015/150208_ BM_M\%C3\%BCSiKo.html

Rede von Bundesverteidigungsminister Theodor $\mathrm{zu}$ Guttenberg auf der 46. Münchner Sicherheitskonferenz im Februar 2010 in München, http://www.polifo.de/uploads/568_Neues _strategisches_Konzept_der_NATO.pdf

STEINMEIER F.W., Dialog obywateli. Berlińskie przemówienie ministra spraw zagranicznych Niemiec z okazji 20-lecia powstania Federalnego Związku Towarzystw Niemiecko-Polskich, 30 IV 2007, „Dialog. Magazyn Polsko-Niemiecki” 2007, nr 77-78, s. 87.

Ukaz Prezydenta Ukrajiny nr 105/2007 pro Strategiju nacjonalnoj bezpeki Ukrajiny, 12 II 2007, maszynopis powielany.

Verteidigungspolitische Richtlinien. Nationale Interessen wahren - Internationale Verantwortung übernehmen - Sicherheit gemeinsam gestalten, Bundesministerium der Vertedigung, Berlin den 27. Mai 2011, http://www.bmvg.de, s. 1-2.

Wir hätten uns mehr Mut gewünscht. Stellungnahme des Ost-Ausschuss-Vorsitzenden Eckhard Cordes zur Verlängerung der Russland-Sanktionen, 17 XII 2015, Ost-Ausschus der Deutschen Wirtschaft, www.ost-ausschuss.de/node/1035

\section{Artykuły prasowe}

Angela Merkel wpada w furię, „Gazeta Wyborcza”, 5 IX 2008.

Getmanthuk A., Est li u Vas plan, frau Merkel?, „Zerkalo nedeli”, 29 X 2005.

Merkel poprawia stosunki z Rosją, „Gazeta Wyborcza”, 3 X 2008.

SCHÄUBLE W., Die europäische Integration voranbringen, „Frankfurter Allgemeine Zeitung”, 28 I 2005.

SCHUlLER K., Westliche Einflussnahme. Der Albtraum ukrainischer Politiker, „Frankfurter Allgemeine Zeitung”, 17 VIII 2015.

Union für Signal der EU an die Ukraine, „Süddeutsche Zeitung”, 29 XII 2005.

\section{Materiały internetowe}

Gabriel wirbt für Aufhebung der Sanktionen gegen Russland, 25 IX 2015, „Süddeutsche Zeitung”, www.sueddeutsche.de/politik/moskaus-rolle-im-syrien-krieg-gabriel-wirbt-fuer-aufhebung-dersanktionen-gegen-russland-1.2666045 
NATO priorytetem Ukrainy. Specjalna uchwała parlamentu, 8 VI 2017, PAP, cyt. za: Polskie Radio, https://www.polskieradio.pl/5/3/Artykul/1774762,NATO-priorytetem-Ukrainy-Specjal na-uchwala-parlamentu

Niemcy przeciw zbrojeniu Ukrainy i nie widzą jej w NATO, PAP, cyt. za: Polskie Radio, 31 VIII 2014, https://www.polskieradio.pl/5/3/Artykul/1219801,Niemcy-przeciw-zbrojeniu-Ukrainyi-nie-widza-jej-w-NATO

Odstraszanie i dialog - szczyt NATO z niemieckiej perspektywy, 10 VII 2016, Defence24, https://www.defence24.pl/odstraszanie-i-dialog-szczyt-nato-z-niemieckiej-perspektywy

SPD-Politiker wollen Sanktionen gegen Putin beenden, 28 IX 2015, „Die Welt”, www.welt. de/politik/deutschland/article146952409/SPD-Politiker-wollen-Sanktionen-gegen-Putin-been den.html

Steinmeier hat Hoffnung auf Ukraine-Gipfel nicht aufgegeben, 15 I 2015, „Die Welt”, www.welt. de/print/die_welt/wirtschaft/article136385771/Steinmeier-hat-Hoffnung-auf-Ukraine-Gipfelnicht-aufgegeben.html

TURKowski A., Ukraina i NATO: granice integracji, 12 VII 2016, Defence24, https://www. defence24.pl/ukraina-i-nato-granice-integracji

Ukraina chce do NATO. Zmiana polityki, 8 VI 2017, Defence24, https://www.defence24. $\mathrm{pl}$ /ukraina-chce-do-nato-zmiana-polityki

Über wirtschaftliche Annaeherung zur politischen Verstaendigung. Grußwort von Eckhard Cordes beim Deutsch-Russischen Wirtschaftsdialog, 9 XI 2015, Ost-Ausschus der Deutschen Wirtschaft, www.ost-ausschuss.de/node/1007

\section{Pozostale}

Badania socjologiczne przeprowadzone przez Ukraińskie Centrum Badań Ekonomicznych i Politycznych im. Ołeksandra Razumkowa, http://www.razumkov.org.ua/ukr/socpolls.php?cat_ $\mathrm{id}=49$

Wywiad z Prezydentem Federacji Rosyjskiej Władimirem Putinem, przeprowadzony w dniu 17 XII 2015 r., wyemitowany w ramach filmu dokumentalnego „Miroporjadok”, autor: Władimir Sołowjow, Kanał: Rossija 1, data emisji: 20 XII 2015, www.youtube.com/watch?v= ZNhYzYUo42g

\section{PROBLEM NATO W RELACJACH NIEMIECKO-UKRAIŃSKICH W XXI WIEKU. ZARYS ZAGADNIENIA}

\section{Streszczenie}

Zakres i intensywność współpracy między RFN i Ukrainą, mimo dużych oczekiwań i nadziei wyrażanych przede wszystkim przez stronę ukraińską, w pierwszych dwóch dekadach XXI wieku nie osiągnął zbyt wysokiego poziomu. Władze niemieckie nie tylko nie wypracowały w tym okresie jasno sprecyzowanej koncepcji politycznej wobec tego kraju, ale stały się nawet jednym z głównych zwolenników realizacji zasady Russia First. Konieczność uwzględnienia przez Berlin przesłanek determinowanych znaczeniem Moskwy dla europejskiego i światowego bezpieczeństwa jest stałym czynnikiem warunkującym pozycję Niemiec w kwestii rozszerzenia NATO o Ukrainę, bez uwzględnienia którego nie można w sposób właściwy zdiagnozować dynamiki relacji niemiecko-ukraińskich. Stanowisko Berlina w tej kwestii charakteryzuje wyraźnie niezmiennie negatywne podejście. Podczas trwającego od 2014 r. rosyjsko-ukraińskiego konfliktu 
zbrojnego Ukraina nie doczekała się zarysowania jasnej perspektywy członkostwa. Co więcej, $\mathrm{w}$ istniejącej sytuacji kwestia ta traktowana jest jako czynnik budujący dodatkowe napięcia i tym samym uniemożliwiający dyplomatyczne przezwyciężenie kryzysu. Tego rodzaju podejście, w warunkach prawdopodobnej permanentności konfliktu, oznacza nie tylko realne zdjęcie kwestii rozszerzenia Sojuszu na Wschód z euroatlantyckiej agendy, ale prawdopodobnie również długotrwałe jej ,zamrożenie”.

Słowa kluczowe: Ukraina; Sojusz Północnoatlantycki; Republika Federalna Niemiec; Federacja Rosyjska; rozszerzenie NATO.

\section{THE NATO PROBLEM IN GERMAN-UKRAINIAN RELATIONS IN THE 21ST CENTURY: OUTLINE OF THE ISSUE}

\section{S u m m a r y}

The scope and intensity of cooperation between Germany and Ukraine, despite high expectations and hopes expressed primarily by the Ukrainian side, have not reached high level in the first two decades of the 21 st century. During this period, the German government has not only failed to develop a clear political concept for Ukraine, but became one of the main supporters of the Russia First principle. Berlin's need to take into account the conditions determined by Moscow's significance for European and global security is a constant factor determining Germany's attitude towards NATO's enlargement to Ukraine without which the dynamics of German-Ukrainian relations cannot be properly understood. Berlin's attitude towards this issue has been clearly and consistently negative. During the Russian-Ukrainian armed conflict, ongoing since 2014, Ukraine has not seen a clear membership perspective. Moreover, in the current situation, this issue is treated as a factor creating additional tensions and thus blocking the diplomatic routes to overcome the crisis. Such an approach, coupled with the probable permanence of the conflict, means that the enlargement of NATO to the East will probably not only be removed from the Euro-Atlantic agenda, but also "frozen" for a long time to come.

Key words: Ukraine; the North Atlantic Alliance; the Federal Republic of Germany; the Russian Federation; NATO enlargement. 